The Common Agricultural Policy of the European Union the present and the future

EU Member States

point of view 



\section{INSTITUTE OF AGRICULTURAL AND FOOD ECONOMICS NATIONAL RESEARCH INSTITUTE}

\section{The Common Agricultural Policy of the European Union - the present and the future}

\section{EU Member States point of view}

Editors:

dr Marek Wigier

prof. dr hab. Andrzej Kowalski

Proceedings of the International Scientific Conference

"The Common Agricultural Policy of the European Union - the present and the future" Multi-Annual Programme 2015-2019

"The Polish and the EU agricultures 2020+. Challenges, chances, threats, proposals" 5-7 December 2017 Stare Jabłonki, Poland

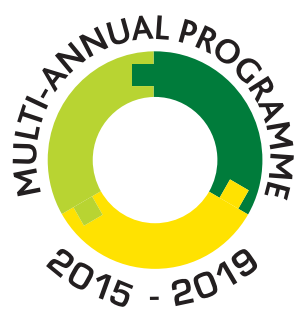

THE POLISH AND THE EU AGRICULTURES 2020+ CHALLENGES, CHANCES, THREATS, PROPOSALS

Warsaw 2018 
This monograph was prepared under the Multi-Annual Programme 2015-2019

"The Polish and the EU agricultures 2020+. Challenges, chances, threats, proposals".

The publication is a collection of selected papers delivered at the 22th edition of the International Scientific Conference organized by the Institute of Agricultural and Food Economics - National Research Institute. The theme of the conference was "The Common Agricultural Policy of the European Union the present and the future. The conference was placed on 5-7 December 2017 in Stary Jabłonki in Poland. Common Agricultural Policy was and still is one of the key pillars of European integration. Published in two volumes materials refer directly to the current and future of the CAP in EU and non EU member states, the strategic objectives and principles of agricultural policy for the agri-food sector and rural areas, address the issues of equilibrium between agriculture, forestry and land use, relate to the dilemmas for the EU budget and the CAP after 2020, CAP instruments and their adjustment, transformations of the rural economy and programming of the rural and agricultural policy, as well as productivity and production efficiency and tensions between sectoral action and between different models of territorial activities.

In the Scientific Committee of the Conference was participated: Prof. Andrzej Kowalski (IAFE-NRI, Poland), Prof. Drago Cvijanonivić (University of Kragujevac, Serbia), Prof. Thomas Doucha (IAEI, Czech Republic), Noureddin Driouech, PhD (CIHEAM, Italy), Prof. Szczepan Figiel (IAFE-NRI, Poland), Prof. Masahiko Gemma (Waseda University, Japan), Prof. Wojciech Józwiak (IAFE-NRI, Poland), Prof. Jacek Kulawik (IAFE-NRI, Poland), Prof. Yuriy Oleksiyovych Lupenko (IAE, Ukraina), Prof. Věra Majerová (CULS, Prague), Prof. Dimitre Nikolov (IAE, Bulgaria), Maire Nurmet, PhD (EMÜ, Estonia), Prof. Gabriel Popescu (ASE, Romania), Norbert Potori, PhD (AKI, Hungary), Prof. Włodzimierz Rembisz (IAFE-NRI, Poland), Piotr Szajner, PhD (IAFE-NRI, Poland), Prof. Alina Sikorska (IAFE-NRI, Poland), Prof. Jonel Subić (IAE, Serbia), Prof. Samuele Trestini (UNIPD, Italy), Prof. Olga Varchenko (Bila Tserkva National Agrarian University, Ukraine), Dipl.-Ing. Klaus Wagner (AWI, Austria), Marek Wigier, PhD (IAFE-NRI, Poland), Prof. Józef St. Zegar (IAFE-NRI, Poland)

In the Organising Committee of the Conference was participated: Małgorzata Bułkowska (IAFE-NRI, Poland), Anna Hankiewicz (IAFE-NRI, Poland), Joanna Jaroszewska (IAFE-NRI, Poland), Joanna Korczak (IAFE-NRI, Poland), Krzysztof Kossakowski (IAFE-NRI, Poland), Irena Mikiewicz (IAFE-NRI, Poland), Małgorzata Mikołajczyk (IAFE-NRI, Poland), Lech Parzuchowski (IAFE-NRI, Poland), Ewa Sierakowska (IAFE-NRI, Poland), Paulina Smakosz (IAFE-NRI, Poland), Leszek Ślipski (IAFE-NRI, Poland), Marek Wigier, PhD (IAFE-NRI, Poland).

Reviewers:

Professor Dimitre Nikolov, Institute of Agricultural Economics, Sofia, Bulgaria

Professor Gabriel Popescu, The Bucharest University of Economic Studies, Bucharest, Romania

Professor Samuele Trestini, University of Padva, Italy

Proofreader

Katarzyna Mikulska

Technical editors:

Joanna Jaroszewska, Barbara Pawtowska, Ewa Sierakowska, Kamila Tomaszewska,

Barbara Walkiewicz

Translated by

Summa Linguae S.A.

Cover Project

Leszek Ślipski

ISBN 978-83-7658-743-1

DOI: $10.30858 / \mathrm{pw} / 9788376587431$

Instytut Ekonomiki Rolnictwa i Gospodarki Żywnościowej

- Państwowy Instytut Badawczy

ul. Świętokrzyska 20, 00-002 Warszawa

tel.: (22) 5054444

faks: (22) 5054636

e-mail:dw@ierigz.waw.pl

http://www.ierigz.waw.pl 


\section{Contents}

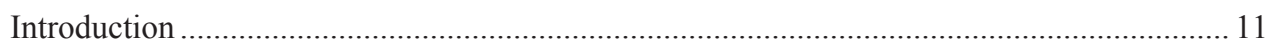

Dr Marek Wigier

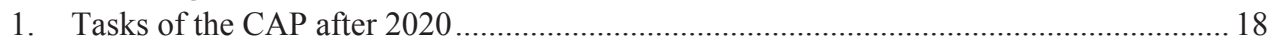

Dr hab. Julian Krzyżanowski

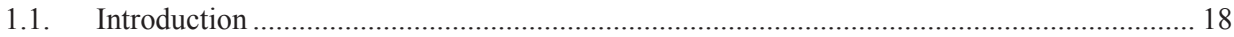

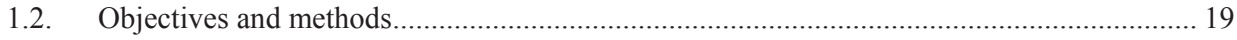

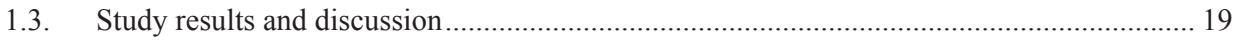

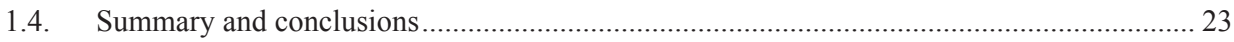

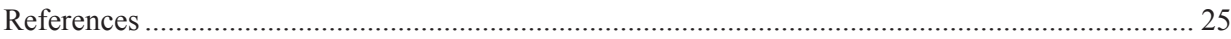

2. An assessment of the regional impacts of post-2020 CAP budgetary cuts on production

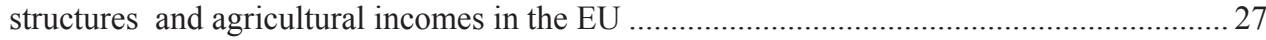

PhD Norbert Potori, PhD János Sávoly, PhD Szabolcs Biró

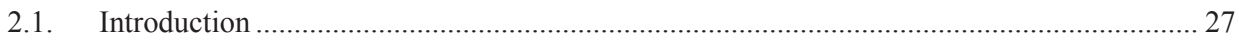

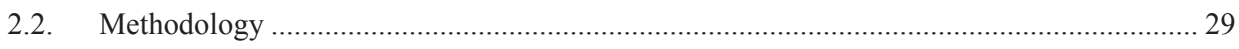

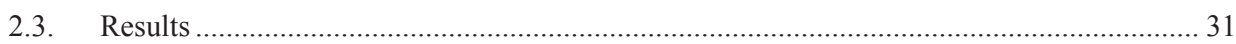

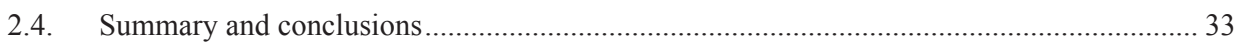

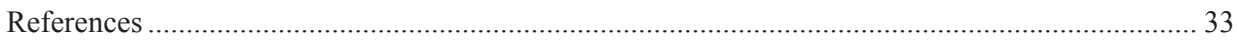

3. Is there room for financial instruments in the Common Agricultural Policy? Casus of

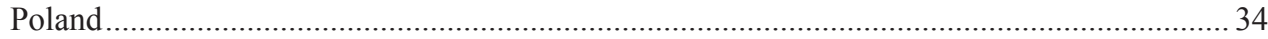

Prof. dr hab. Jacek Kulawik, PhD Barbara Wieliczko, PhD Michat Soliwoda

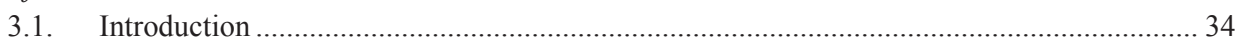

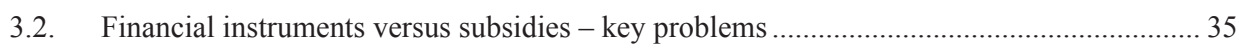

3.3. The use of financial instruments under the EU policy ......................................................... 37

3.4. Example of the use of FI in the 2014-2020 programming period ......................................... 38

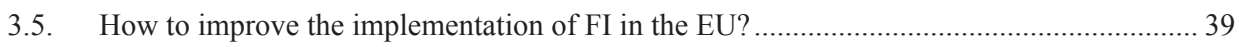

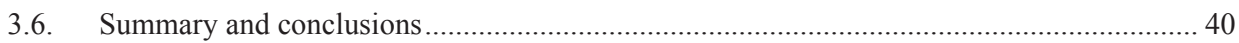

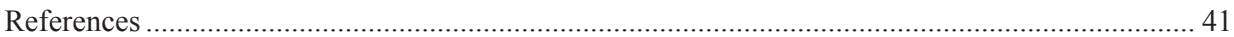

4. The past, present and future of the CAP - the Hungarian viewpoint ............................. 43

Dr Tamás Mizik

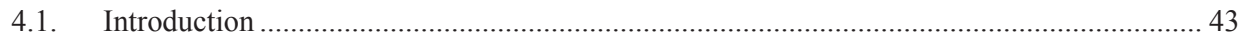

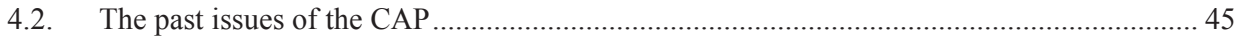

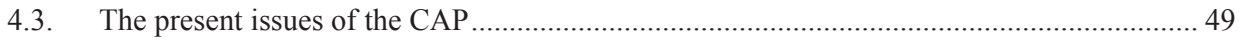

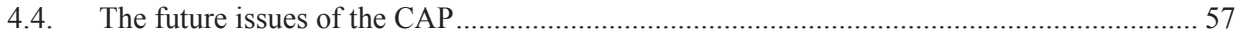

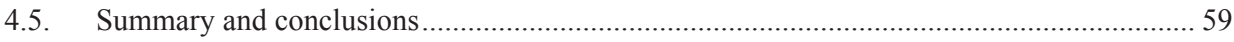

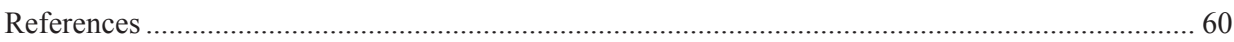


5. Going beyond the Rural Development Programme: a Master Plan for Austria's rural areas in the framework of the CAP

Dip.-Ing. Klaus Wagner

5.1. Introduction

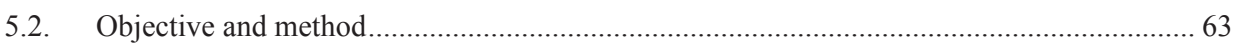

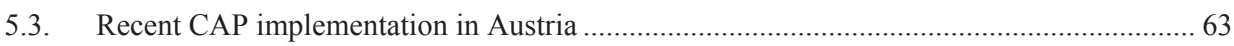

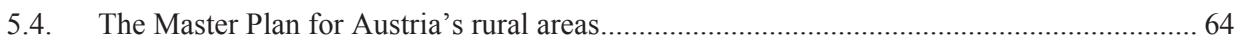

5.5. CAP in the system of the EU policy objectives and in the view of regional science

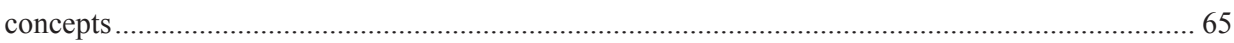

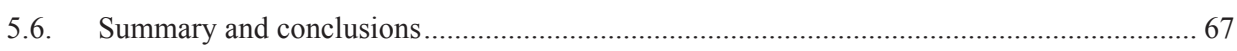

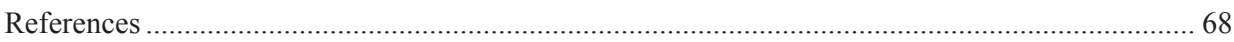

6. Possibilities to connect the Romanian agricultural research to the market requirements 69 Prof. Gabriel Popescu

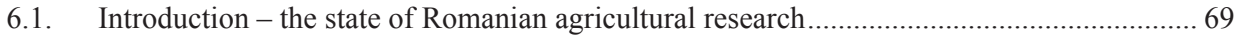

6.2. The problems faced by agricultural research since 1990 ..................................................... 71

6.3. Possible solutions for the recovery of Romanian agricultural research ................................ 76

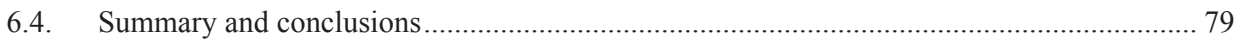

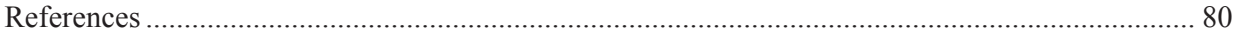

7. Price relationships of the production factors as exogenous determinants of production in agriculture.

Prof. dr hab. Włodzimierz Rembisz, PhD Adam Waszkowski

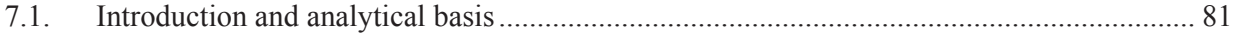

7.2. Relationships of prices of the capital, labour and land factors - hypothetical approach...... 83

7.3. Relationships of prices of the capital, labour and land factors - empirical approach .......... 84

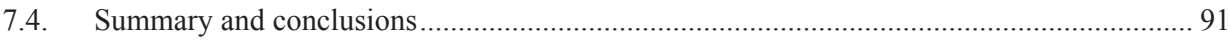

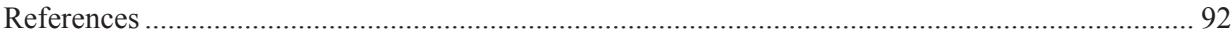

8. Effects of direct payments on agricultural development in Bulgaria ............................. 93 PhD Bozhidar Ivanov

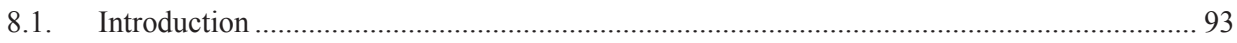

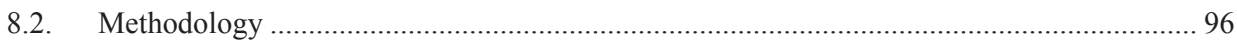

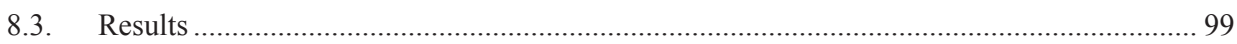

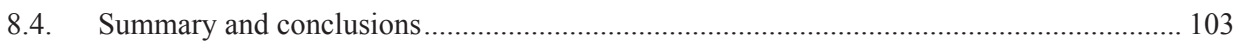

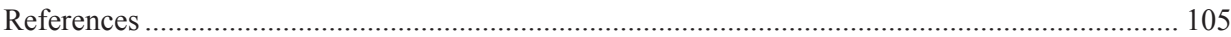

9. Re-adjusting risk management within the CAP: evidences on the implementation of the

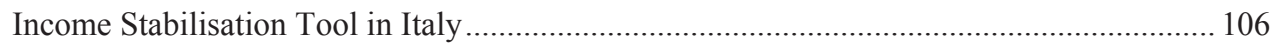
Prof. Samuele Trestini, PhD Elisa Giampietri

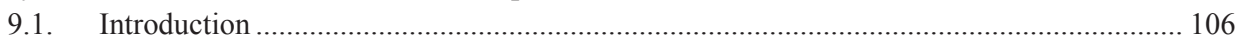

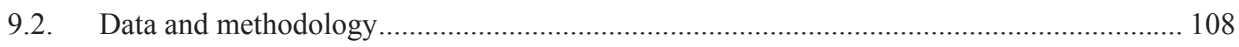




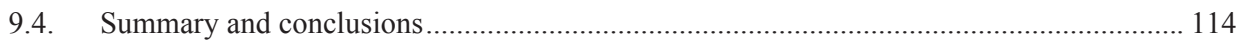

References

10. Comparison of risk management tools under the CAP of the EU, the US Farm Bill

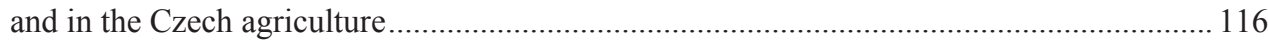
Ing. Václav Vilhelm, CSc., Ing. Sumudu Namali Gouri Boyinová, PhD Jindřich Špička

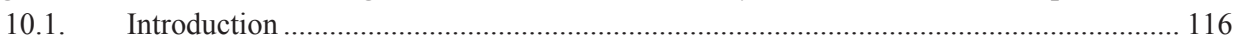

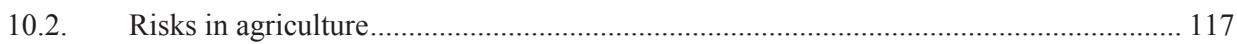

10.3. Risk management policy in the United States Farm Bill 2014 _..................................... 118

10.4. Risk management policy of the European Union's CAP ................................................ 119

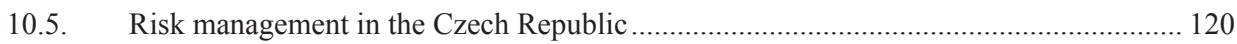

10.6. Comparative analysis of risk management policies ........................................................ 121

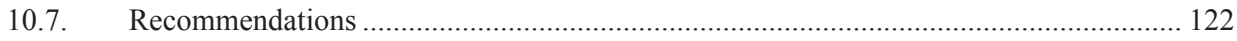

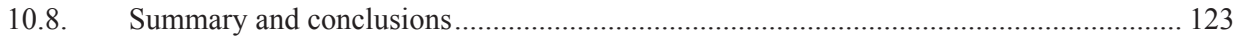

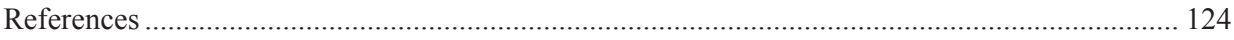

11. Factors determining the crop insurance level in Poland taking into account the level

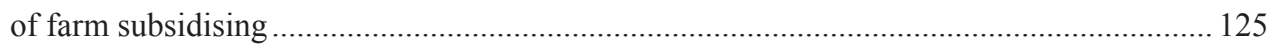

Prof. Adam Was, PhD Pawet Kobus

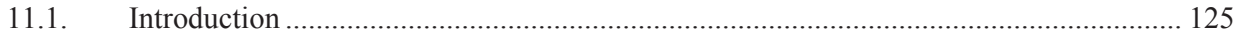

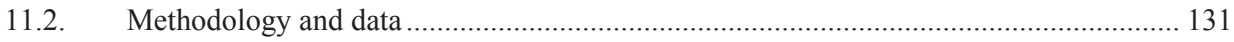

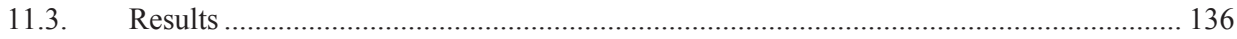

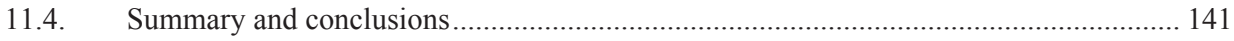

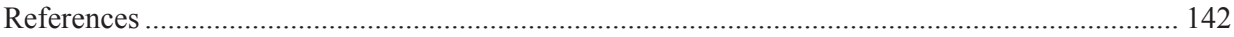

12. Farms and agricultural enterprises for development of sustainable and smart cooperatives: a multifactor approach using digital farm management ............................... 147 Prof. dr habil Adriana Mihnea, Prof. dr Dimitre Nikolov, dr Krasimir Kostenarov

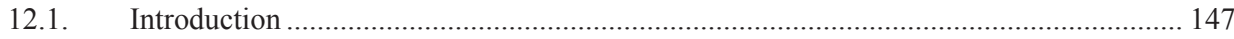

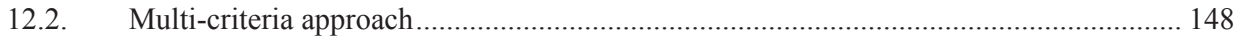

12.3. Construction of Farm Management Model ................................................................ 150

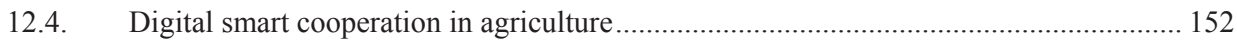

12.5. Application of the ANP Farm Management Model ....................................................... 154

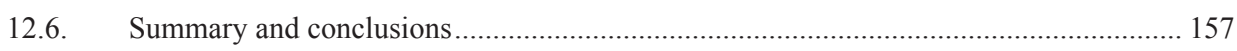

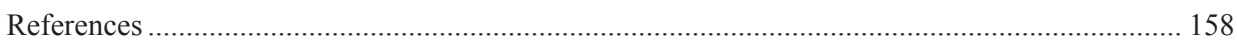

13. Brexit - potential implications for the Polish food sector .............................................. 159

Dr Katarzyna Kosior, Dr Łukasz Ambroziak

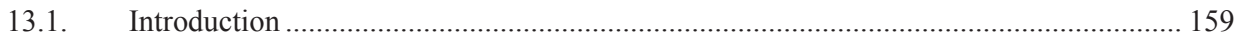

13.2. Negotiations on Brexit - what should be the model of the future relations? ..................... 161

13.3. The future of the EU finances and the CAP in the context of Brexit .............................. 163 
13.4. Impact of possible changes in the CAP budget on the net balance of Poland and transfers to the Polish agriculture.

13.5. The potential impact of Brexit on agri-food trade between Poland and the United

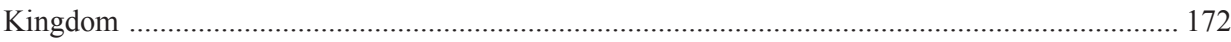

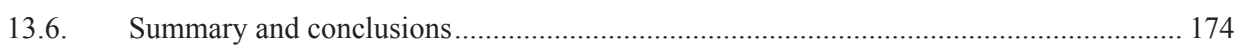

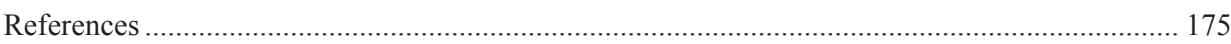

14. The Transatlantic Trade and Investment Partnership (TTIP): a threat or an opportunity for the EU-Mediterranean agriculture and agri-food sector? An exploratory survey ........... 177 Dipl.-Ing. Katja Pietrzyck, PhD Noureddin Driouech, Prof. Brigitte Petersen

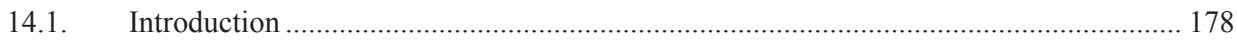

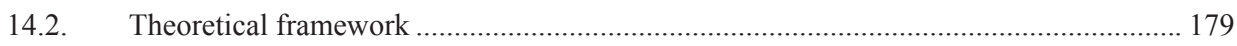

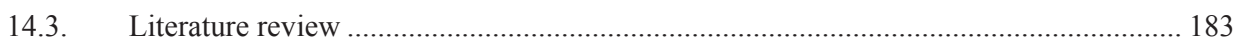

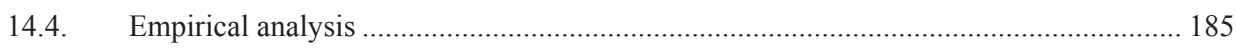

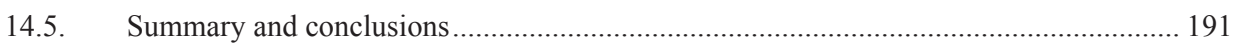

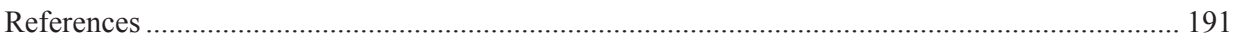

Appendix I: Overview of trade statistics regarding selected products ........................................... 195

15. The concept of short supply chains in the food economy............................................. 196

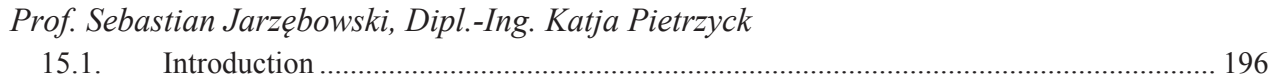

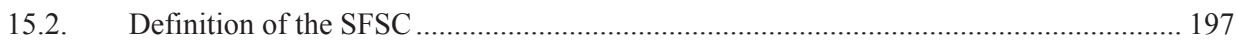

15.3. Development of short supply chains in Europe............................................................. 201

15.4. Global context of European short supply chains ........................................................... 205

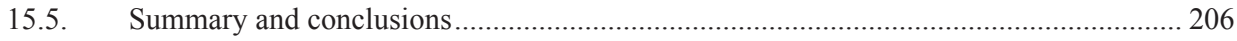

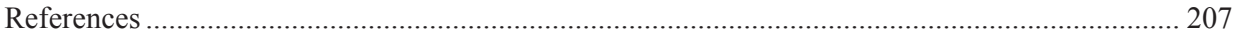

16. The CAP implementation in Wallonia - today performance and questions for the future -

A brief supplementary comment from Warmia and Mazury perspective............................. 209

PhD Philippe Burny, PhD Benon Gazinski

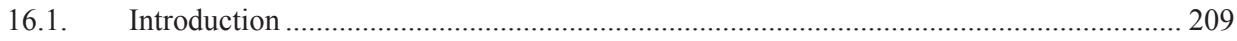

16.2. Implementation of the green payment in Wallonia in 2015 ........................................ 210

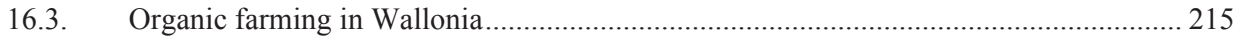

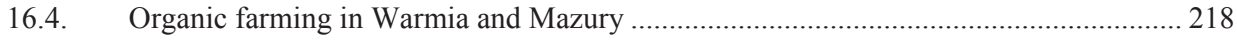

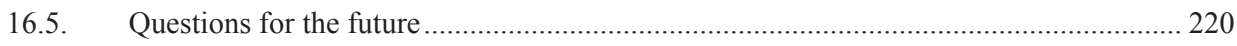

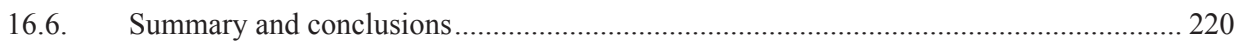

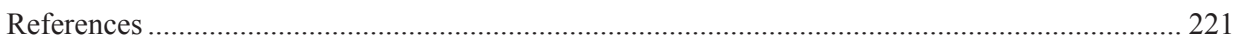

17. Afforestation of agricultural land financed from the RDP 2014-2020 ....................... 224

PhD Marek Zieliński

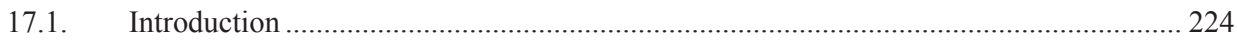

17.2. Natural farming conditions in Poland in regional terms................................................. 225 
17.3. The impact of natural farming conditions in Poland on the economic situation and the possibility of afforestation on farms

17.4. Land afforestation financed from the RDP 2014-2020 in regional terms

17.5. Importance of land afforestations financed under the RDP 2014-2020 in the EU climate policy for 2021-2030.

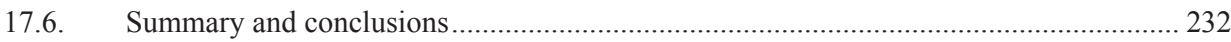

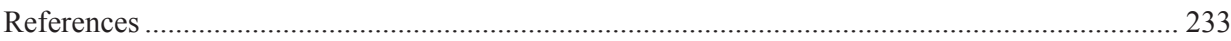

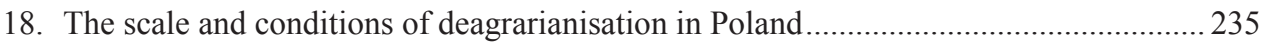

PhD Michat Dudek, PhD Bożena Karwat-Woźniak

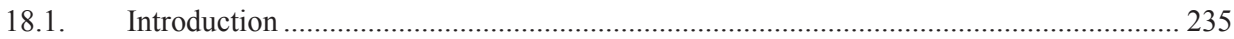

18.2. The conditions of the decrease in employment in agriculture ......................................... 236

18.3. The change in the scale of employment in agriculture in Poland and its conditions....... 238

18.4. The instruments of the Cohesion Policy and agriculture and rural development of the EU

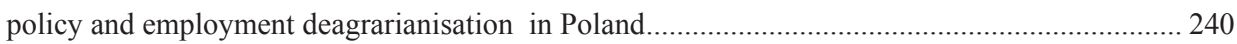

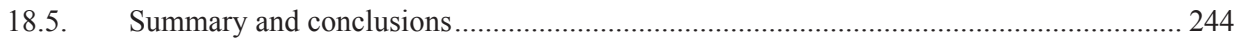

References 245

19. Socio-economic and environmental parameters and results of rural development under the CAP: the case of Bulgaria ................................................................................................ 247 Prof.dr.hab. Julia Doitchinova, Prof.dr.hab. Ivan Kanchev, Ass.Prof. Ralitsa Terziyska PhD, Ass.Prof. Kristina Todorova PhD

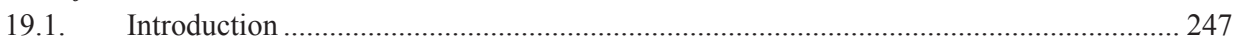

19.2. Changes in Bulgarian rural areas - socio-economic and environmental aspects................ 248

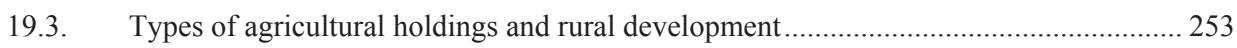

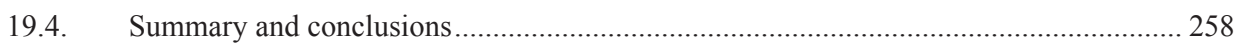

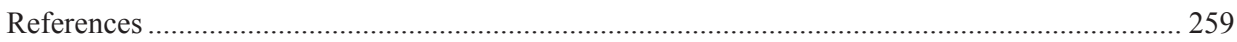

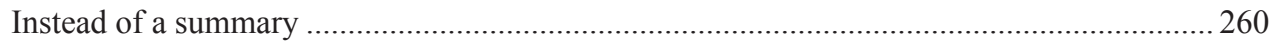

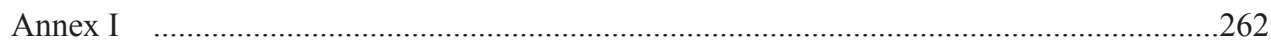




\title{
2. An assessment of the regional impacts of post-2020 CAP budgetary cuts on production structures and agricultural incomes in the $\mathbf{E U}$
}

\author{
PhD Norbert Potori, PhD János Sávoly, PhD Szabolcs Biró \\ Research Institute of Agricultural Economics, Budapest, Hungary \\ potori.norbert@aki.gov.hu,savoly.janos@aki.gov.hu, \\ biro.szabolcs@aki.gov.hu
}

DOI: $10.30858 / \mathrm{pw} / 9788376587431.2$

\begin{abstract}
The European Commission (EC) will publish its post-2020 Multi-Annual Financial Framework (MFF) for the European Union (EU) before summer 2018. The EC sees the status quo as no option for the EU. In designing the new MFF, coherence and complementarity between the different programmes and instruments will be strengthened, and flexibility would be factored in to respond to the new challenges and unexpected developments. In consequence, the funding of the Common Agricultural Policy (CAP) is expected to decrease and have a lower share in the overall EU spending after 2020.

This paper assesses the regional impacts of a hypothetical $30 \%$ and $15 \%$ cut in the EU CAP budget, supplemented by a BREXIT scenario (the United Kingdom (UK) being a net budgetary contributor), on both agricultural production structures and incomes in the EU. To this end, projections by the Common Agricultural Policy Regional Impact Analysis (CAPRI) simulation model were prepared, and shifts in agricultural production and changes in income distribution were briefly evaluated.
\end{abstract}

Keywords: Common Agricultural Policy, post-2020 Multi-Annual Financial Framework, direct payments, CAPRI model

JEL codes: C53, Q11, Q18

\subsection{Introduction}

Any restructuring of the $\mathrm{CAP}$ is dependent on the finalisation of the next (2021-2027) EU budget framework. The MFF provides the basis for the EU to implement common policies with European value added. The White Paper on the Future of Europe [European Commission, 2017a] set out several possible scenarios for Europe's future. The Reflection Paper on the Future of the EU Finances [European Commission, 2017b] looked at what each of these scenarios could mean for the EU budget, from 'step back to only the Single Market' to the 'lot more together' option, accompanied by a reliable budget that allows the 
efficient delivery of priorities. The leaders of the EU and its Member States agreed on a positive agenda for the Europe of 27 in Bratislava on 16 September 2016 and in the Rome Declaration of 25 March 2017.

The withdrawal of the UK from the EU will mean the loss of a significant contributor to the financing of the EU's policies and programmes. Haas and Rubio [2017] calculated the UK annual net contribution to the CAP at around EUR 3 billion above the allocated expenditures. There is no easy way of adjusting CAP spending to fill in the 'Brexit' gap. They also estimated that higher contributions would affect the biggest net contributors the most, while reducing CAP spending puts a higher burden of adjustment on CAP net recipients. This means that a critical look must be taken at where savings can be made and priorities delivered more efficiently. This is an essential part of the preparation of any budget proposal and the EC is fully committed to modernising and streamlining wherever possible. In the 'Brexit' negotiations, disadvantages for the future MFF have to be minimised. In the MFF negotiations, the increase of the resources and the cutbacks should not be limited to any particular spending area due to mitigating adverse effects on the different policies.

In the view of the EC [European Commission, 2017c], the CAP has successfully integrated the related horizontal and sectoral policies and, at the same time, serves to realise commercial, environmental, climate, and research and innovation goals. The CAP has also strengthened the EU's leadership role in the world market for agricultural and food products; adjusted prices to the world market and ensured income stability in the volatile market environment. Most EU citizens agree that the CAP generates significant EU added value and functions as a public good [ECORYS, 2017]. According to the public opinion, the CAP guarantees the high quality and safety of food, and there is an expectation that the EU will raise farmers' living standards and strengthen their role in the food chain. In the EC's vision, besides the results, more emphasis should be placed on both the environmental and economic sustainability of the CAP. In addition to covering the cost of 'Brexit' and the new challenges (common defence, migration and counter-terrorism), resources from traditional policies (i.e. the CAP and Cohesion Policy) may also be necessary in the context of the negotiation of the 2021-2027 MFF.

After the adoption of the EC's Communication [European Commission, 2017c] on the future CAP in November 2017, the Committee on Agriculture and Rural Development of the European Parliament was convened on 4 December 2017. In its opinion, the Committee urged the EC to increase, or at the very least to maintain at its current level, the EU CAP budget post-2020 [Ribiero, 2018]. In the Agriculture Council meeting of 11-12 December 2017, Ministers had their 
first opportunity to react to the Communication and highlight the strategic issues for the future CAP. Many Ministers stressed the need for an adequate future budget to match the high expectations placed on the agri-food sector. The Committee also stressed the need for the EC to keep direct payments intact, as they help to avoid distortions of competition between Member States, and to maintain the external competitiveness of the EU agricultural products. Impact assessment on the implementation of the current Common Monitoring and Evaluation Framework of the CAP, including the first results on the performance, will be presented to the European Parliament and the European Council in April 2018. Discussions on the MFF beyond 2020 could start at the earliest in May 2018. The negotiations on the legislative proposal are planned to begin in the second half of 2018.

The EU Budget Commissioner Günther Oettinger highlighted the need for proportionate budgetary cuts to 'plug the gap' as a result of 'Brexit', and for extra financial contributions from Member States to add to the challenges of the refugee crisis, the protection and monitoring of borders and security concerns [Agra Facts, 2017].

In this paper, the regional impacts of hypothetical cuts in the CAP budget due to 'Brexit' and to the restructuring of the EU budget after 2020 are assessed. To this end, three different scenarios were developed for which projections by the CAPRI simulation model were prepared. The estimated shifts in both agricultural production structures and agricultural incomes in the EU are briefly evaluated in the paper.

\subsection{Methodology}

For estimating the regional impacts of cuts in the post-2020 CAP budget on both production structures and agricultural incomes in the EU, the CAPRI simulation model was used. CAPRI is a global, comparative static, partial equilibrium model for primary and secondary agricultural commodities designed for the ex ante assessment of impacts caused by changes in the EU's CAP instruments with a focus on the EU Member States and NUTS 2 level [Leip et al., 2011].

The main assumptions of the CAPRI baseline ('CAP 2014-2020' as of 2016) used for this assessment were that the CAP 2014-2020 remains unchanged, except for its financing; agricultural trade policy measures of the EU are governed by the Uruguay Round Agreement on Agriculture without considering any bilateral trade agreements still under negotiation in 2016; and the EU Renewable Energy Directive [2009] continues in effect. 
The following three different scenarios were developed and assessed:

- $\quad$ BREXIT: The assumption was that the UK formally departs the EU in 2019 and its financial contribution to the EU CAP budget, estimated at around EUR 4.44 billion, will be not compensated. Therefore, the UK's net contribution of around EUR 3 billion [Haas and Rubio, 2017] missing from the CAP for the remaining 27 Member States was distributed between Pillar 1 and Pillar 2 as per the weights of the EU direct payments and the EU rural development support, resulting in, respectively, 5.94\% and $6.39 \%$ decrease in the two EU CAP financial envelopes for 2020 . The financial ceilings for the EU direct payments and the EU rural development support of the 27 Member States were reduced evenly by the same percentages. The share of each not fully exploited EU direct support scheme (i.e. redistributive payments, voluntary coupled support schemes, payments for young farmers, etc.) was allowed to increase up to the limits in each Member State as laid down in Regulation (EU) No. 1307/2013.

- CAP - 15\%: Based on Agence Europe [2017], an overall cut of $15 \%$ in the EU CAP budget was assumed, including BREXIT. Above the commitments allocated to the UK, the EU CAP spending for the remaining 27 Member States was reduced by EUR 3.41 billion, resulting in a further $6.77 \%$ and $7.28 \%$ decrease in the funding of Pillar 1 and Pillar 2, respectively, for 2020. The financial ceilings for the EU direct payments and the EU rural development support of the 27 Member States were reduced evenly by the same percentages. The share of each not fully exploited EU direct support scheme was allowed to increase up to the limits in each Member State as laid down in Regulation (EU) No. 1307/2013.

- $\quad$ CAP -30\%: an overall cut of 30\% in the EU CAP budget was assumed, including BREXIT. Above the commitments allocated to the UK, EU CAP spending for the remaining 27 Member States was reduced by EUR 11.58 billion, resulting in a further $22.93 \%$ and $24.66 \%$ decrease in the funding of Pillar 1 and Pillar 2, respectively, for 2020. The financial ceilings for the EU direct payments and the EU rural development support of the remaining 27 Member States were reduced evenly by the same percentages. Again, the share of each not fully exploited direct support scheme was allowed to increase up to the limits in each Member State as laid down in Regulation (EU) No. 1307/2013.

In each scenario, the financial transfers between the EU direct payments and the EU rural development support for each Member State were considered as laid down in Article 14 of Regulation (EU) No. 1307/2013. 


\subsection{Results}

Table 1 summarizes the model results for those arable crops which are of significant importance from the perspective of Hungary. In each of the above scenarios, relatively small adjustments in the sowing areas for these crops are projected versus the CAPRI baseline, except for soybeans. The area under soybeans is expected to shrink by over 9\% (CAP -30\%) in the EU-13 (Member States joining the EU since 2004). Soybean production has been encouraged by voluntary coupled support, often exceeding the basic or single area payment, in various Member States (e.g. including Hungary and Romania) since 2015, but its competitiveness still lags behind rapeseed and sunflower seed production. As for soft wheat and grain maize production, the EU-14 ('old' Member States less the UK) could gain some comparative advantage by cuts in CAP spending, while for rapeseed and especially for sunflower seed production, the opposite would be true. At the level of the EU-27, the area under cereals and oilseed are expected to decrease by up to $1.7 \%$ and slightly over $1 \%$, respectively (CAP -30\%). As for changes in producer incomes, a decline in the EU financial support could have aworse impact on arable farmers in the EU-13, especially in the case of soft wheat production.

Table 1. CAPRI model results for crop production: changes versus the baseline

\begin{tabular}{|l|r|r|r|r|r|r|r|r|r|r|}
\hline & \multicolumn{4}{|c|}{ BREXIT } & \multicolumn{3}{c|}{ CAP -15\% } & \multicolumn{3}{c|}{ CAP -30\% } \\
\cline { 2 - 12 } & \multicolumn{9}{|c|}{ Changes in cropping area (\%) } \\
\cline { 2 - 12 } & EU-27 & EU-13 & EU-14 & EU-27 & EU-13 & EU-14 & EU-27 & EU-13 & EU-14 \\
\hline Cereals & -0.91 & -0.79 & -0.99 & -0.93 & -0.81 & -1.03 & -1.54 & -1.34 & -1.69 \\
\hline Soft wheat & 0.32 & -0.09 & 0.62 & 0.31 & -0.10 & 0.60 & -0.03 & -0.41 & 0.24 \\
\hline Grain maize & 0.14 & 0.05 & 0.26 & 0.14 & 0.06 & 0.26 & 0.09 & -0.04 & 0.26 \\
\hline Oilseeds & -0.55 & -0.45 & -0.63 & -0.56 & -0.46 & -0.65 & -0.95 & -0.82 & -1.04 \\
\hline Rapeseed & -0.49 & -0.39 & -0.55 & -0.50 & -0.39 & -0.57 & -0.64 & -0.41 & -0.78 \\
\hline Sunflower & -0.43 & -0.14 & -0.77 & -0.44 & -0.12 & -0.80 & -0.59 & -0.05 & -1.34 \\
\hline Soybeans & -1.88 & -2.82 & -0.78 & -2.10 & -3.14 & -0.89 & -6.34 & -9.25 & -2.98 \\
\hline & & & \multicolumn{7}{|c|}{ Changes in producer incomes (\%) } & \\
\hline Cereals & -5.12 & -6.47 & -4.39 & -5.48 & -6.88 & -4.72 & -14.06 & -14.75 & -13.65 \\
\hline Soft wheat & -3.50 & -6.49 & -2.09 & -3.84 & -6.91 & -2.38 & -12.67 & -15.07 & -11.55 \\
\hline Grain maize & -3.38 & -3.54 & -3.28 & -3.65 & -3.86 & -3.50 & -10.04 & -9.97 & -10.17 \\
\hline Oilseeds & -5.50 & -6.72 & -4.90 & -5.77 & -7.17 & -5.09 & -13.88 & -15.71 & -13.00 \\
\hline Rapeseed & -5.06 & -6.96 & -4.30 & -5.27 & -7.35 & -4.45 & -12.84 & -14.71 & -12.07 \\
\hline Sunflower & -6.18 & -6.48 & -5.84 & -6.58 & -7.03 & -6.14 & -15.95 & -17.38 & -14.80 \\
\hline Soybeans & -6.64 & -5.93 & -7.55 & -6.93 & -6.40 & -7.78 & -14.49 & -15.26 & -15.46 \\
\hline
\end{tabular}

Source: own calculations.

Table 2 summarizes the model results for the major livestock sectors, excluding sheep and goats. In the CAPRI baseline, incomes for beef farmers are projected to be negative, this explains the decline in the beef herd in each of the scenarios. Beef production is strongly subsidized in most Member States by the means 
of coupled support. The apparent gain in incomes for beef farmers in the EU-14 hints at their relative competitiveness improving when CAP spending is reduced, although beef farming is still expected to yield, on average, no profit for them.

An anticipated increase in milk producer prices in the CAPRI baseline compensates for the cuts in the EU direct payments received by dairy farmers, including voluntary coupled support applied extensively by many Member States. Therefore, both milk production and incomes of dairy farming are expected to grow in each of the scenarios.

Pig fattening is indirectly impacted by the cuts in the EU area-based payments. A slight increase in feed costs due to the decline in cereals and oilseeds area would substantially affect this sector, which is to be explained by the very low absolute value of unit income generated as per the CAPRI baseline. Pig fattening would, on average, continue making losses.

The exposure of the laying-hens sector to changes in the EU direct support seems to be limited compared to the production of broilers. In the CAPRI baseline, incomes for broiler producers in the EU are, on average, projected as negative, although the absolute values in unit terms are, just as in the case of pig fattening, rather low. Hence the high changes in percentage terms. Negative changes in the number of broilers mean that cuts in the EU direct payments would put a brake on the increase in the production of broilers as projected in the CAPRI baseline, driven by only a few Member States (e.g. Poland or Spain) where production yields profit.

Table 2. CAPRI model results for livestock farming: changes versus the baseline

\begin{tabular}{|c|c|c|c|c|c|c|c|c|c|}
\hline & \multicolumn{3}{|c|}{ BREXIT } & \multicolumn{3}{|c|}{ CAP $-\mathbf{1 5 \%}$} & \multicolumn{3}{|c|}{ CAP $-30 \%$} \\
\hline & \multicolumn{9}{|c|}{ Changes in livestock numbers $(\%)$} \\
\hline & EU-27 & EU-13 & EU-14 & EU-27 & EU-13 & EU-14 & EU-27 & EU-13 & EU-14 \\
\hline Beef" & -1.06 & -1.12 & -1.05 & -1.09 & -1.14 & -1.08 & -1.59 & -1.61 & -1.59 \\
\hline Milk $^{* *}$ & 0.57 & 0.37 & 0.62 & 0.57 & 0.37 & 0.62 & 0.55 & 0.23 & 0.62 \\
\hline Pig fattening & -1.50 & -0.63 & -1.65 & -1.50 & -0.63 & -1.66 & -1.54 & -0.68 & -1.69 \\
\hline Laying hens & -0.29 & -0.12 & -0.38 & -0.30 & -0.12 & -0.39 & -0.34 & -0.15 & -0.44 \\
\hline \multirow[t]{2}{*}{ Broilers } & -4.93 & -3.29 & -5.55 & -4.93 & -3.29 & -5.55 & -4.98 & -3.34 & -5.59 \\
\hline & \multicolumn{9}{|c|}{ Changes in producer incomes $(\%)$} \\
\hline Beef* & 3.92 & -2.97 & 5.96 & 3.78 & -3.06 & 5.80 & 0.82 & -4.89 & 2.50 \\
\hline Dairy $^{* * *}$ & 3.34 & 9.48 & 2.93 & 3.34 & 9.40 & 2.94 & 3.22 & 7.50 & 2.92 \\
\hline Pig fattening & -23.12 & -29.64 & -22.97 & -23.13 & -29.67 & -22.97 & -23.42 & -31.05 & -23.21 \\
\hline Laying hens & -1.59 & -0.54 & -2.31 & -1.59 & -0.55 & -2.31 & -1.73 & -0.66 & -2.47 \\
\hline Broilers & -17.31 & -21.38 & -17.11 & -17.31 & -21.39 & -17.11 & -17.44 & -21.67 & -17.22 \\
\hline
\end{tabular}

* Other cows, heifers for fattening low/high weight, male adult cattle low/high weight.

** Milk production.

*** Dairy cows low/high yield, heifers breeding, raising male/female calves, fattening male/female calves.

Source: own calculations. 


\subsection{Summary and conclusions}

In the three scenarios developed for assessing the impacts of cuts in the CAP budget due to 'Brexit' and to the restructuring of the EU budget after 2020 on both agricultural production structures and incomes in the EU, there were relatively small adjustments in the sowing areas of the major cereals and oilseeds, except for soybeans. Our modelling results showed a much wider diversity for the possible structural changes in the livestock sectors. In general, a larger decline in incomes for all agricultural sectors, except for milk production, might be expected in the EU-13 due to a shrinking CAP budget, which hints at the EU agricultural subsidies playing a more pronounced role in ensuring a stable source of income for farmers in the 'new' Member States. However, the CAPRI baseline market assumptions were found to have a strong influence on the estimated impacts of changes in the EU CAP budget, therefore, especially in the case of the livestock sectors, the modelling results should be interpreted with much caution.

\section{References}

1. Agence Europe (2017). Europe Daily Bulletin No. 11911. Retrieved from: https://agenceurope.eu/en/bulletin/article/11911/6

2. ECORYS (2017). Modernising and simplifying the CAP Summary of the results of the public consultation. Retrieved from: https://ec.europa.eu/agriculture/sites/ agriculture/files/consultations/cap-modernising/summary-public-consul.pdf.

3. European Commission (2017a). White Paper on the Future of Europe, Reflections and scenarios for the EU27 by 2025.

4. European Commission (2017b). Reflection Paper on the Future of EU Finances, 28 June 2017.

5. European Commission (2017c). Communication from the Commission to the European Parliament, the Council, the European Economic and Social Committee and the Committee of the Regions The Future of Food and Farming, Brussels, 29.11.2017 COM(2017) 713 final.

6. Haas, J., Rubio, E. (2017). Research for AGRI Committee - Possible impact of Brexit on the EU budget and, in particular, CAP funding, European Parliament, Policy Department for Structural and Cohesion Policies, Brussels.

7. Leip, A., Weiss, F., Britz, W. (2011). Agri-Environmental Nitrogen Indicators for EU27, in: Flichman G. (ed.), Bio-Economic Models applied to Agricultural Systems, Springer, Netherlands, pp. 109-124.

8. Regulation (EU) No 1307/2013 of the European Parliament and of the Council of 17 December 2013 establishing rules for direct payments to farmers under support schemes within the framework of the common agricultural policy and repealing Council Regulation (EC) No 637/2008 and Council Regulation (EC) No 73/2009.

9. Ribieiro, S. (2018). Opinion on the next MFF: Preparing the Parliament's position on the MFF post-2020 AGRI_AD(2018)612377. 